\title{
A symbiosis between renewable energy and tourism: The case of Dnipro region in Ukraine
}

\author{
Hanna Shevchenko ${ }^{1, *}$ and Mykola Petrushenko ${ }^{1}$ \\ ${ }^{1}$ Institute of Market Problems and Economic-Ecological Research of the National Academy of Sciences of Ukraine, Department of \\ Economic Management of Natural Resources, 65044 Odesa, Ukraine
}

\begin{abstract}
Transition economies have less ambition to achieve the 2030 Sustainable Development Goals in comparison with developed economies. However, if to compare the benchmarks under Goal 9 "Affordable and clean energy" for Ukraine with the trends of its energy balance, the satisfaction of the relevant ambitions is possible only with a comprehensive approach. Purpose of the study is to analyse the multifaceted innovative intersectoral cooperation and inclusion of energy-tourism projects in the regional socio-economic and ecological programs, in accordance with the reference benchmarks under SDGs in Ukraine. The paper has outlined an approach to activation the relationship between renewable energy and tourism sphere, on the example of solar power plants in the Dnipro region. Implementation of the proposed, in the study, part of the regional program will create opportunities: for tourism sphere - improving the tourist image of the region, increasing in the number of domestic tourists, creating new jobs, increasing in volume of tourist services, increasing in revenues from tourism to regional and local budgets; for renewable energy sphere: also improving an image and information policy, increasing in number of future customers, generating additional income, improving indicators of social and environmental effectivness. The proposals set out in the paper will serve in the future as basis for the development of the ideas of energy-tourism symbiosis within the European Green Deal.
\end{abstract}

\section{Introduction}

According to the provisions of the European Green Deal, climate change policy and clean and affordable energy also have social, economic and environmental aspects that are organically linked to the 2030 Sustainable Development Goals. One of the forms of activating the socio-economic role of renewable energy is its synergy with other sustainable spheres, such as tourism. If the positive impact of "green" energy policy on tourism sphere is clear and widely disclosed, then the reverse impact needs further coverage. Understanding, that such a symbiotic relationship is rather an exception, especially in transition economies, we will present arguments and justify the benefits for the Ukrainian energy and tourism spheres that are possible with the implementation of effective organizational steps. As an example, in the paper we consider the project for the tourism development on the territory of the Nikopol and Pokrov solar power stations in the Dnipro region [1,2], which is also a benchmark for investment in the framework of regional planning in the context of expanding intersectoral relationships. The national nature parks are missing in this region, so the creation of a new tourism destination does not contradict the tourism policy of the region [3] and the growing demand for industrial tourism, in particular, within the network of industrial parks development [4]. Innovative energy of the region, in turn, will improve its image in accordance with the concept of social responsibility. In particular, the funds received from tourism can be used for the inclusive development of "green" and wellness recreation $[5,6]$ and environmental protection in one of the largest industrial regions of Ukraine.

With appropriate support and coordination of state and regional authorities, the tourism and energy business has a chance for realization its innovative potential not only in the economic but also in the social and environmental context. This will allow increasing the competitiveness of Ukrainian business at the international level and promoting the attraction of foreign investment both in tourism and renewable energy field.

The paper analyses the multifaceted innovative intersectoral cooperation and develops early propositions for the inclusion of energy-tourism projects in the regional socio-economic and ecological programs, in accordance with the reference benchmarks under Goal 7 "Affordable and clean energy" and Goal 9 "Industry, innovation and infrastructure" in Ukraine.

\section{Methodology}

The conceptual basis of the study was the provisions of sustainable development and their evolution in the form of a set of Sustainable Development Goals 2030 and the

*Corresponding author: hannashevchenko@gmail.com 
European Green Deal. The theoretical basis of the article also included interdisciplinary approaches to the study of intersectoral interaction, namely between tourism and energy, taking into account innovative factors.

The research methods included structural and comparative analysis - in the study of SDGs Ukraine, namely renewable energy and innovation sphere indicators within Goal 7 and Goal 9, as well as the energy balance of Ukraine. In addition, elements of the scenario method were used - in substantiating the implementation of the energy-tourism projects (related to the Nikopol SPS and Pokrov SPS) in the context of the tourism development program and the complex program of ecological security and climate change in Dnipro region of Ukraine, 2021-2022.

\section{Results}

The logic of the study consisted in the realization of a sequence of such stages: to clarify the possibilities of interaction between the energy and tourism sectors on the principles of sustainability in Ukraine, to substantiate the proposals for their use to improve regional tourism and renewable energy programs at the regional level in compliance with the European Green Deal.

\subsection{SDGs and energy balance of Ukraine}

If in setting of the standards of development of renewable energy to focus only on the trends in table 1 (compiled by the authors according to the National Review [7]), then they look like very ambitious. Especially, if to rely on the innovativeness of economic development. It is clear, that factors such as the impact of the coronavirus, the delay in the transition period, as well as the antagonistic conflict in eastern Ukraine, do not add optimism about the prospects for sustainable development in the country. While at the same time very ambitious projects have been introduced, in particular the construction of the Nikopol and Pokrov solar power stations, which is a great event in the real sector of the Ukrainian economy, which should receive further development in other areas.

Table 1. SDGs Ukraine: renewable energy and innovation sphere indicators within Goal 7 and Goal 9.

\begin{tabular}{|l|c|c|c|}
\hline \multicolumn{1}{|c|}{ Indicator, compared to 2015,\% } & 2018 & 2025 & 2030 \\
\hline $\begin{array}{l}\text { Share of energy produced from } \\
\text { renewable sources in total final } \\
\text { energy consumption }\end{array}$ & 143 & 290 & 349 \\
\hline $\begin{array}{l}\text { Energy intensity of GDP (primary } \\
\text { energy consumption per unit of } \\
\text { GDP), kg of oil equivalent per } \\
\text { USD1 by PPP 2011 }\end{array}$ & 95 & 60 & 50 \\
\hline $\begin{array}{l}\text { Share of expenditure on scientific } \\
\text { research and development in GDP }\end{array}$ & 85 & 364 & 545 \\
\hline $\begin{array}{l}\text { Share of sales of innovative } \\
\text { products in total sales of } \\
\text { industrial products }\end{array}$ & 57 & 714 & 1071 \\
\hline
\end{tabular}

A more detailed picture can be seen in the data of the energy balance of Ukraine in Fig. 1 and Fig. 2 (compiled by the authors on the basis of the data of the State Statistics Service of Ukraine [8]). In practice, energy production in Ukraine is mainly traditional sources (coal and peat, crude oil and petroleum products, natural gas, hydropower, electricity and heat energy) - about $65 \%$ of the total structure of energy production. Also, about $30 \%$ is nuclear energy. Among non-traditional sources, the development of energy production from biofuels and waste has some positive trends - about $4 \%$ of all energy. The development of solar and wind energy is slower: together they account for less than $1 \%$ of the total structure of energy production in Ukraine.

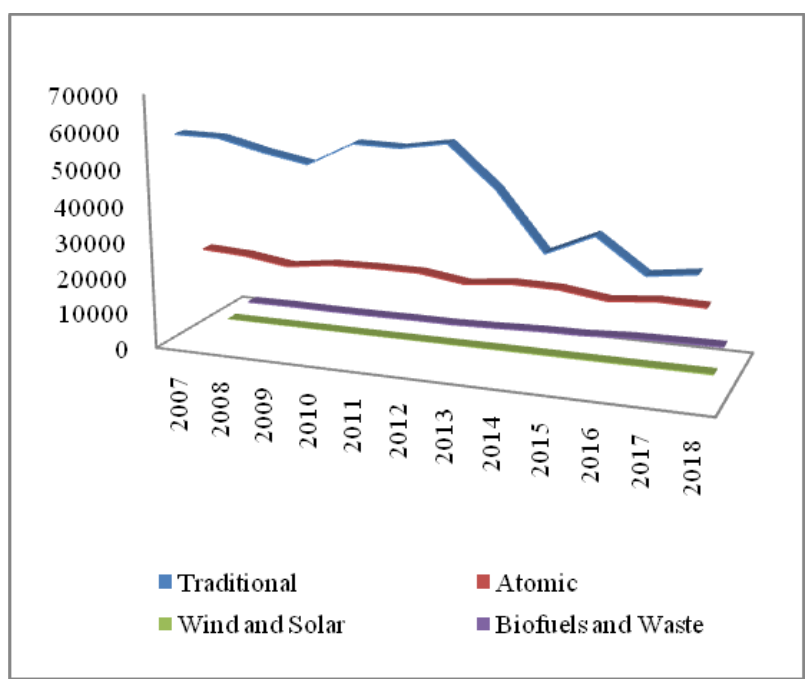

Fig. 1. Energy production in Ukraine, thousand tons of oil equivalent, 2007-2018.

In the field of tourism, as well as in the whole sphere of services, there is practically no positive trend in the development of renewable energy consumption. Wind and solar energy are not consumed at all (Fig. 2). Therefore, in the practical plane of the Ukrainian economy it is necessary to activate intersectoral cooperation not only in the direction of "tourism - renewable energy", but also in the opposite direction way.

The analysis of the indicators dynamics in Table 1, supplemented by the study of trends in Ukraine's energy balance, in particular, in the context of energy consumption by services sphere, suggests that the satisfaction of ambition for sustainable energy development in the country by 2030 requires a comprehensive approach to formulating an appropriate strategy at the national and regional levels. Innovations should be not only economic or technological, but also organizational.

The tourism-energy project, mentioned above, is focused on organizing trips in order for tourists to get the experience from visiting of solar power plants in the Dnipro region. The positive experience of mining tourism, as well as the projected development of the domestic tourism market in Ukraine during forced isolation are prerequisites for initiation intra-regional 
tourist routes in the direction of Nikopol and Pokrovskaya solar stations, located in a picturesque area of the Ukrainian steppe).

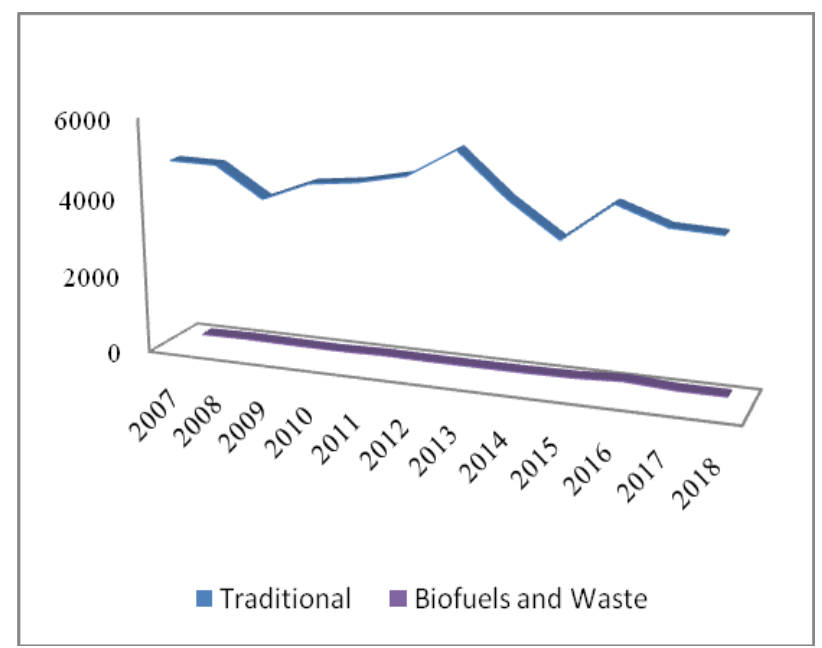

Fig. 2. Energy consumption by services, including tourism, in Ukraine, thousand tons of oil equivalent, 2007-2018.

The capacity of Nikopol SPS is 300 million $\mathrm{kWh}$ (design capacity of Pokrovskaya SPS is 400 million $\mathrm{kWh}$ ). The station has 750,000 panels on an area of 400 hectares, as well as a special observation deck [1,2].

The location of these power plants in the natural environment, the possibility of developing tourist routes near them, the economic potential of mutually beneficial transfers in the intersectoral context (including in other industries, in particular, in agriculture [9]) - all this encourages the search for new management decisions based on the principles of strategic planning: from the global to the national and regional levels. At the same time, according to the priorities of the European Green Deal [10], any innovations in the energy sector are directly related to the environmental factor (tourism as a socio-economic and natural-oriented sphere is no exception [11]). In order to reach the climate-neutral mark in 2050 , we already have to formulate ambitious goals and tasks in short-, medium-, and long-term plans and programs. And this requires the search for all kinds of opportunities for innovative development and the use of intersectoral cooperation, involving social, cultural, geographical, political and other factors. In order for the measures declared in the programs to be realistic, clear actions are needed to regulate relations in the field of tourism [12] and in the field of energy. At the same time, the role of the state should be focused on establishing the rules of the game in the markets of tourism and renewable energy, as well as supporting socially and environmentally oriented projects.

\subsection{Regional programs of tourism and renewable development}

To implement the Nikopol and Pokrovsk SPSs touristical project at the regional level, its implementation in the tourism development program in Dnipro region until 2022 [7] is required. Table 2 proposes in the relevant sections of the program the measures, the amount of investment, as well as the benefits of the project.

In the long perspective, such projects can form a network of tourist routes, and therefore it would be appropriate to consider the possibility of their cooperation with a network of industrial parks in Ukraine.

A comprehensive approach to taking into account the multifaceted relationships between the studied areas of economic development involves the introduction of appropriate innovative measures in the programs of the Dnieper region on:

- the innovation development 2020 (development of innovation infrastructure);

- the international, European integration processes and the formation of a positive image 2020 (compliance with the European Green Deal);

- the development of the agro-industrial complex 2021 (product quality standards, "green" tourism);

- the employment 2022 (new jobs);

- the support of the population in energy saving of the housing sector 2020 (development of renewable energy in the territories of communities);

- the protection and defense of intellectual property 2020 (development of scientific and technical potential in the field of modern environmentally friendly, safe, energy and resource-saving technologies);

- the intensification of the development of small and medium enterprises by 2020 (business participation in solving socio-environmental issues in the region).

\section{Discussion}

Thus, Ukraine has one of the largest solar power plants in Europe, which can also be used as a great attraction for tourism development in the country, in particular, in the most industrially developed Dnipro region. Energytourism projects considered in the study related to the Nikopol SPS and Pokrov SPS, need support at the regional level and, accordingly, should be implemented in the framework of the regional tourism development program 2022. The studied intersectoral interaction is potentially beneficial both for tourism sphere and for renewable energy, as well as for the sustainable development of the region. But at the same time, given the consequences of the COVID-19 pandemic, measures should be carried out with maximum compliance with tourist safety requirements, in particular, in accordance with the standards ISO 22300 Security and resilience [13]. The peculiarity of "energy tourism" is that even during a pandemic it is possible to create conditions for excursions to the power plant with the provision of related recreational services: firstly, such destinations have enough space for visitors, including in the natural environment; secondly, they are located outside the city, which allows to avoid crowds and organize travel in various formats. In other words, energy-tourism projects are a realistic alternative, compared to traditional types of tourism, to meet the needs of the population in travel and recreation in conditions of forced isolation and enhanced security. 
Table 2. The implementation of the energy-tourism projects in the context of the tourism development program and the complex program of ecological security and climate change in Dnipro region of Ukraine, 2021-2022

I The concept of the program

Consistency with the Sustainable Development Goals 2030

Consistency with the European Green Deal 2030, 2050

\begin{tabular}{|l|l|l|}
\hline Scenario & \multicolumn{1}{|c|}{ Pessimistic } & \multicolumn{1}{c|}{ Optimistic } \\
\hline Traditional development & $\begin{array}{l}\text { The consequences of the pandemic } \\
\text { crisis, as well as the lack of stability in } \\
\text { the development of socio-economic } \\
\text { processes in Ukraine will not allow to } \\
\text { successfully implement the program }\end{array}$ & $\begin{array}{l}\text { European integration processes are the key to } \\
\text { eliminating contradictions in the development of } \\
\text { the Ukrainian economy and significant support for } \\
\text { the implementation of energy and resource-saving } \\
\text { projects }\end{array}$ \\
\hline Innovation development & $\begin{array}{l}\text { Without economic stability, it is } \\
\text { impossible to implement large-scale } \\
\text { innovation projects }\end{array}$ & $\begin{array}{l}\text { Renewable energy, innovation in the field of } \\
\text { environmental protection, as well as their } \\
\text { relationship with such socially oriented spheres as } \\
\text { tourism, are vectors of the European Green Deal }\end{array}$ \\
\hline
\end{tabular}

Participation of the state and other stakeholders: research institutions, business representatives, public organizations

II The implementation of the program

\begin{tabular}{|c|c|c|c|c|c|c|}
\hline \multirow[b]{2}{*}{$\begin{array}{l}\text { Measures } \\
\text { (projects) }\end{array}$} & \multirow[b]{2}{*}{ Terms } & \multirow[b]{2}{*}{$\begin{array}{c}\text { Responsible } \\
\text { executors }\end{array}$} & \multicolumn{3}{|c|}{ Investments, thousand UAH } & \multirow[b]{2}{*}{$\begin{array}{l}\text { Expected results / indicators of } \\
\text { measures (projects) }\end{array}$} \\
\hline & & & $\begin{array}{l}\text { Foreign } \\
\text { investors }\end{array}$ & $\begin{array}{c}\text { Budgets of } \\
\text { different } \\
\text { levels }\end{array}$ & $\begin{array}{l}\text { Ukrainian } \\
\text { investors }\end{array}$ & \\
\hline
\end{tabular}

Symbiotic development of tourism and energy industry: interaction of economic, social, cultural factors

Priority 1. Development of sustainable tourism

\begin{tabular}{|c|c|c|c|c|c|c|}
\hline $\begin{array}{l}\text { Popularization of } \\
\text { the regional tourist } \\
\text { potential }\end{array}$ & \multirow{4}{*}{$\begin{array}{l}2020- \\
2022\end{array}$} & \multirow{4}{*}{$\begin{array}{l}\text { Department of } \\
\text { Economic } \\
\text { Development, } \\
\text { Department of } \\
\text { Ecology and } \\
\text { Natural Resources, } \\
\text { Department of Mass } \\
\text { Communications, } \\
\text { Department of } \\
\text { Education and } \\
\text { Science }\end{array}$} & 500.0 & 200.0 & 400.0 & $\begin{array}{l}\text { Number of events, excursions } \\
\text { and tourists }\end{array}$ \\
\hline $\begin{array}{l}\text { Development of } \\
\text { tourist } \\
\text { infrastructure }\end{array}$ & & & 5000.0 & 3000.0 & 2500.0 & Number of equipped routes \\
\hline Information support & & & 450.0 & 250.00 & 200.00 & $\begin{array}{l}\text { Number of created thematic } \\
\text { plots }\end{array}$ \\
\hline $\begin{array}{l}\text { Exercises and } \\
\text { conferences }\end{array}$ & & & 300.0 & 200.0 & 100.00 & $\begin{array}{l}\text { Number of employees who } \\
\text { have improved their skills }\end{array}$ \\
\hline Priority 2. Developn & 01 & wable energy & & & & \\
\hline $\begin{array}{l}\text { Promotion of } \\
\text { renewable energy } \\
\text { in Ukraine }\end{array}$ & & $\begin{array}{l}\text { Department of } \\
\text { Economic }\end{array}$ & 100.00 & 50.00 & 70.00 & $\begin{array}{l}\text { Number of events, excursions } \\
\text { and visitors }\end{array}$ \\
\hline $\begin{array}{l}\text { Information } \\
\text { support }\end{array}$ & $\begin{array}{l}2020- \\
2022\end{array}$ & $\begin{array}{l}\text { Department of } \\
\text { Ecology and }\end{array}$ & 250.0 & 100.00 & 100.00 & $\begin{array}{l}\text { Number of created thematic } \\
\text { plots }\end{array}$ \\
\hline $\begin{array}{l}\text { Exercises and } \\
\text { conferences }\end{array}$ & & $\begin{array}{l}\text { Natural Resources, } \\
\text { Department of Mass } \\
\text { Communications }\end{array}$ & 100.0 & 60.0 & 30.00 & $\begin{array}{l}\text { Number of employees who } \\
\text { have improved their skills, } \\
\text { number of participants and } \\
\text { students }\end{array}$ \\
\hline
\end{tabular}

\section{Conclusion}

The paper has outlined an approach to activation the relationship between renewable energy and tourism sphere, on the example of Ukrainian solar energy. The analysis of the energy balance of the country has showed that in the field of tourism, as well as in the whole sphere of services, there is practically no positive trend in the development of renewable energy consumption. Wind and solar energy are not consumed at all. Therefore, in the practical plane of the Ukrainian economy it is necessary to activate intersectoral cooperation not only 
in the direction of "tourism - renewable energy", but also in the opposite direction way.

Ukraine has one of the largest solar power plants in Europe, which can also be used for tourism development in the country, in particular, in the most industrially developed Dnipro region. Energy-tourism projects considered in the study related to the Nikopol SPS and Pokrov SPS, need support at the regional level and, accordingly, should be implemented, including, in the framework of the regional tourism development program and the complex program of ecological security and climate change in Dnipro region of Ukraine, 2021-2022. Implementation of the proposed, in the study, part of the regional program will create opportunities: for tourism sphere - improving the tourist image of the region, increasing in the number of domestic tourists, creating new jobs, increasing in volume of tourist services, increasing in revenues from tourism to regional and local budgets; for renewable energy sphere: also improving an image and information policy, increasing in number of future customers, generating additional income, improving indicators of social and environmental effectivness. The rationale for the proposals set out in the paper is at an early research state, but they reflect conceptual approaches to the implementation of the Sustainable Development Goals, in particular the development of renewable energy in transition economies, and will serve in the future as basis for the development of the ideas of energy-tourism symbiosis within the European Green Deal 2030, 2050.

This research is part of the National Academy of Science of Ukraine's grant "Formation and use of natural-resource assets of the recreational and tourism sphere"

\section{References}

1. Nikopol SPS will be made one of the centers of tourism in Dnipro region / Ukrinform (2020). Available at: https://www.ukrinform.ua/rubrictourism

2. Ministry of Energy and Environment Protection. Unified register for environmental impact assessment (2020). Available at: http://eia.menr.gov.ua/uk/case/id-2998

3. Region programs / Dnipropetrovsk Oblast Rada. (2020). Available https://oblrada.dp.gov.ua/region-programmes/

4. M. M. Petrushenko, H. M. Shevchenko, N. O. Vernydub, O. V. Kravchenko, N. V. Ovcharova, The forming of industrial and national natural parks networks in Ukraine based on the principles for responsible investment, Financial and credit activity: problems of theory and practice, 4(31), 221-229 https://doi.org/10.18371/fcaptp.v4i31.190880

5. H. Shevchenko, M. Petrushenko, B. Burkynskyi, N. Khumarova, Y. Opanasiuk, Management of wellness and recreation in urban agglomerations, Problems and Perspectives in Management, 18(1),
231-241

https://doi:10.21511/ppm.18(1).2020.20

6. M. Petrushenko, H. Shevchenko, B. Burkynskyi, N. Khumarova, A game-theoretical model for investment in inclusive recreation and wellness in Ukraine: the regional context, Investment Management and Financial Innovations, 16(4), 382394 http://dx.doi.org/10.21511/imfi.16(4).2019.32

7. Sustainable Development Goals Ukraine / Voluntary National Review (2020). Available at: https://sustainabledevelopment.un.org/content/docu ments/26295VNR_2020_Ukraine_Report.pdf

8. Energy balance of Ukraine / State Statistics Service of Ukraine (2020). Available at: http://www.ukrstat.gov.ua/operativ/operativ2012/en erg/en_bal/arh_2012.htm

9. H. M. Shevchenko, V. M. Pakhomov, M. M. Petrushenko, Economic and legal issues of rural and recreational land use in Ukraine, Economic Annals$X X I, \quad$ 1-2(156), $\quad 54-58 \quad$ (2016) https://doi.org/10.21003/ea.V156-0012

10. European Commission website. A European Green Deal (2020). Available at: https://ec.europa.eu/info/strategy/priorities-20192024/european-green-deal_en

11. A. Sharif, S. Saha, N. Campbell, A. Sinha, D. M. Ibrahiem, Tourism, environment and energy: an analysis for China, Current Issues in Tourism (2019) https://doi:10.1080/13683500.2019.1703913

12. H. M. Shevchenko, Regulatory policy and optimization of investment resource allocation in model of functioning recreation industry, Baltic Journal of Economic Science, 3(1), 109-115 (2017) http://dx.doi.org/10.30525/2256-0742/2017-3-1$109-115$

13. ISO. COVID-19 response: freely available ISO standard. (Apr. 2020). Available at: https://www.iso.org/covid19 